\title{
VaRTM成形を応用したCFRP部材による圧縮力 を受ける鋼部材の補修・補強に関する研究
}

\author{
松山 晃大 1 ・佐藤 潤 2 タイ ウィサル 3 ・中村 一史 4 ・ \\ 松本 幸大 5 - 松井 孝洋 6 - 越智 寛 7 \\ 1学生会員 首都大学東京 大学院 博士前期課程 都市環境科学研究科都市基盤環境学域 \\ ( (192-0397 東京都八王子市南大沢1-1) \\ E-mail: matuyama-akihiro@ed.tmu.ac.jp \\ 2学生会員 首都大学東京 大学院 博士前期課程 都市環境科学研究科都市基盤環境学域 \\ （干192-0397 東京都八王子市南大沢1-1） \\ E-mail: sato-jun1@ed.tmu.ac.jp \\ 3学生会員 首都大学東京 大学院 博士後期課程 都市環境科学研究科都市基盤環境学域 \\ ( ₹192-0397 東京都八王子市南大沢1-1) \\ E-mail: thay-visal@ed.tmu.ac.jp \\ 4正会員 首都大学東京准教授 大学院 都市環境科学研究科都市基盤環境学域 \\ ( (192-0397 東京都八王子市南大沢1-1) \\ E-mail: hnaka@tmu.ac.jp \\ 5正会員 豊橋技術科学大学准教授 建築・都市システム学系 \\ ( †441-8580 愛知県豊橋市天伯町雲雀ヶ丘1-1) \\ E-mail: y-matsum@ace.tut.ac.jp \\ 6正会員 東レ株式会社 ACM技術部（干103-8666 東京都中央区日本橋室町2-1-1） \\ E-mail: Takahiro_Matsui@nts.toray.co.jp \\ 7正会員＼cjkstart東レ株式会社 アドバンスドコンポジットセンター \\ （干455-8502 愛知県名古屋市港区大江町9番の1） \\ E-mail: Yutaka_Ochi@nts.toray.co.jp
}

\begin{abstract}
本研究は，断面欠損した鋼構造物に，真空含浸（VaRTM）によりCFRP部材を短工期で一体化させて補 修する工法の開発を目的としたものである。はじめに，多積層の炭素繊維（CF）シートのVaRTM成形に よる含浸・接着の方法について, CFシートの積層数, 含浸方向をパラメータとして検討した. 次に, 多層 のCFシートが接着された鋼板の座屈実験を, 積層数をパラメータとして行って, 補強効果を検証した. さ らに，断面欠損を模擬した桁端柱部材にCFRP部材をVaRTM成形により接着して補修し，耐荷力の性能回 復を実験的に検討した。断面欠損部の不陸修正の有無, ソールプレートのアンカーボルトの干涉の影響, CFシートを束ねて積層したプリフォーム（PF）材の適用性の検討を行った.
\end{abstract}

Key Words : steel compression member, repair and strengthening, VaRTM, CFRP, bonded joint

\section{1. はじめに}

鋼鈑林橋の損傷要因の大半は腐食であり，主に桁端部 で多く発生している1). 断面欠損した桁端部の残存而荷 力は，実験的，解析的に検討されている2).

一般に，鋼部材の断面欠損には，高力ボルト接合によ る当て板工法が用いられ，孔明けが必要となる。これに 対して，炭素繊維強化プラスチック（Carbon Fiber
Reinforced Plastic; CFRP) 接着工法 ${ }^{33}{ }^{4}$ は，鋼部材に接着剂 を用いて接合する工法であり，孔明けが不要であるため, 既設部材への影響は少ない，CFRP接着工法は，施工時 に大掛かりな設備を必要としないことや，工期の短縮が 可能となるなど，従来の当て板工法りに比べて多くの利 点がある.

一方，CFRP接着工法の課題として，帯板のCFRP板を 適用する場合，部材間の不陸，連結構造，溶接接合部の 
ような平滑ではない不連続部での接合は困難である，炭 素繊維（CF） シートは，このような平滑ではない不連 続部にも適用できるが，薄いため，積層数が増大寸ると 作業効率が悪くなる．したがって，多積層のCFシート を，現場で急速に施工できる接合方法があれば非常に有 用である.

本研究は，機械分野における，旅客機の構造材や，風 力発電設備のブレード等, 大型 FRP 構造物の製造方法 である，真空含浸工法（Vacuum assisted Resin Transfer Molding; VaRTM）とよばれる成形技術を応用して, CFRP と既設鋼構造物を一体化させる工法 ${ }^{9}$ の開発を目 的としている. 図-1に, VaRTM成形を応用した鋼板への CF シートの含浸・接着の概念図を示寸．この工法は CF シートの積層接着であるため，CFRP による基本的な補 修効果は, 既存の CF シートの含浸接着工法と同等であ るが，既存工法との相違は，積層数に関係なく，一度に 樹脂を含浸できるため，工期を大幅に短縮できること， また, VaRTM 成形後の CFRP の厚さがほぼ均一に仕上 がること，内在するボイドがほぼゼロとなることから， CFRP が安定した品質になる点が挙げられる.ただし， 施工実績がほとんどなく，施工時に真空含浸など，特殊 な作業を含むことから，施工法の確立と補修・補強効果 の検証が必要である.

ここでは，VaRTM 成形を応用することで，多積層の CF シートの接着接合を可能にし，圧縮力を受ける鋼部 材の補修・補強への適用性を検証するために，実験的， 解析的な検討を行った.

はじめに, 多積層の CF シートの VaRTM 成形による 含浸・接着の方法について, CF シートの積層数, 含浸 方向をパラメータとして検討した. 次に, 多積層 CF シ 一トが接着された鋼板の座屈実験を，積層数をパラメー タとして行って, 補強効果を検証した. さらに, 断面欠 損を模擬した林端柱部材に CFRP 部材を VaRTM 成形に より接着して補修し，而荷力の性能回復を実験的に検討 した. 断面欠損部の不陸修正の有無, ソールプレートの アンカーボルトの干渉の影響, CF シートを束ねて積層 したプリフォーム（PF）材の適用性の検討を行った.

\section{VaRTM 成形による多層接着の方法と検証実験}

\section{（1） 材料特性と樹脂の含浸方法}

表-1に，CFシートの材料物性值を示す，CFシートは， 一方向材の高強度タイプを用いた. 含浸接着樹脂には, コンクリート構造物の補修・補強で一般に用いられてい る常温硬化型二液性エポキシ樹脂（AUP40）を適用した.

VaRTM成形により，CFシートに樹脂を含浸寸る場合， 樹脂は, CFシートの表層に配置された, 樹脂拡散メデ
イアに先に含浸し，CFシートの表層から下層に向かっ て樹脂の含浸が徐々に進行する. 樹脂拡散メディアの材 質はポリプロピレンであり，厚さ0.63mm，一辺が $2.5 \times$ 2.5mmのメッシュ状のシートである. 空隙が大きいため, 樹脂の流動性を確保する役割がある. 表層のCFシート への樹脂の含浸は，バギングフィルムとよばれる，透明 なプラスチックフィルムの上から目視で確認できるが, 最下層への樹脂の含浸は，目視で確認できない，そこで， 鋼板をガラス板に置き換え, ガラス板の裏面から最下層 への樹脂の含浸を目視で確認することとした．表層部全

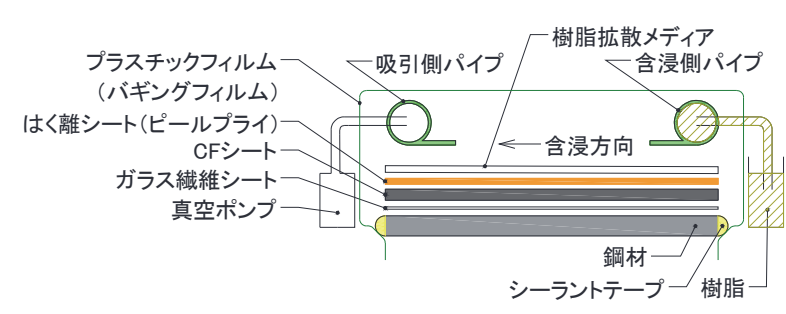

図-1 VaRTM成形を応用した鋼板へのCF シートの 含浸・接着の概念図

表-1 CF シートの材料物性值

\begin{tabular}{l|c}
\hline 引張弾性係数 $\left(\mathrm{kN} / \mathrm{mm}^{2}\right)$ & 245 \\
\hline 引張強度 $\left(\mathrm{N} / \mathrm{mm}^{2}\right)$ & 3400 \\
\hline 設計厚さ $(\mathrm{mm} / \mathrm{ply})$ & 0.167 \\
\hline 繊維重量 $\left(\mathrm{g} / \mathrm{m}^{2}\right)$ & 300 \\
\hline 繊維体積含有率 $(\%)$ & 50 \\
\hline
\end{tabular}

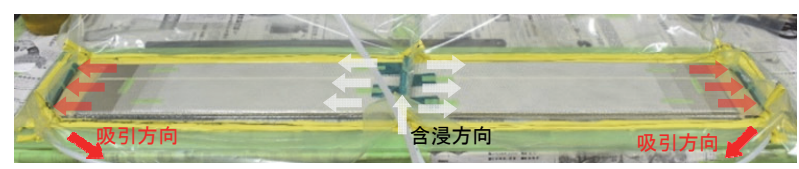

(a) $0^{\circ}$ 方向含浸 (10層)

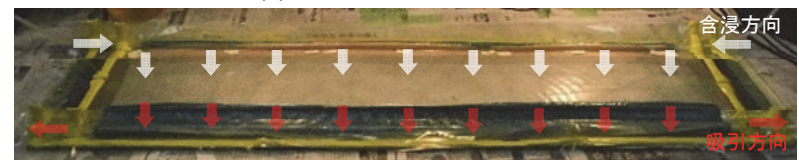

(b) $90^{\circ}$ 方向含浸 (10 層)

写真-1 資材の設置状況

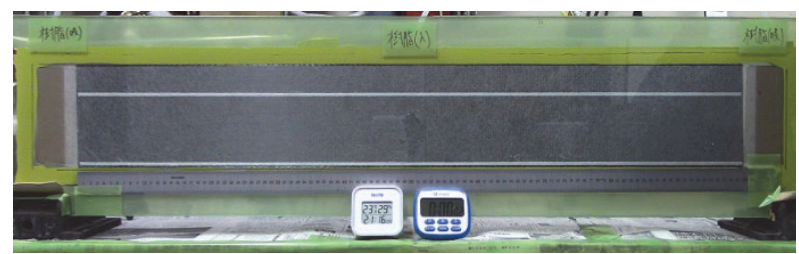

(a)サーフェスマット (SM)

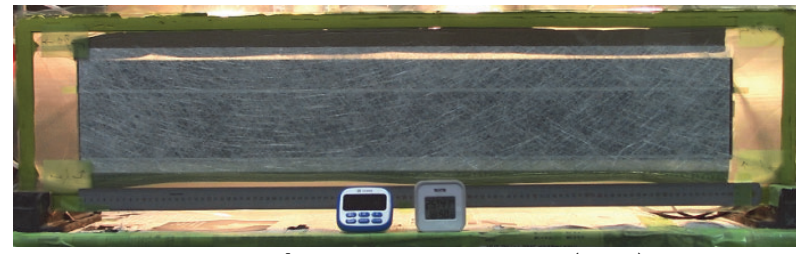

(b) チョップドストランドマット (CSM)

写真-2 最下層へのガラス繊維の設置状況 
体が樹脂拡散メディアを通じて先に含浸するため, 最下 層のCFシートが最も含浸が遅い部位となるためである。

樹脂の含浸方向は，鋼板の長手方向に対して，一方向 材のCFシートを繊維方向（軸方向）に設置する場合を $0^{\circ}$ とし， $0^{\circ}, 90^{\circ} の 2$ 種類を設定し，樹脂の含浸方向の差異 を検討した。

写真-1に， $0^{\circ} ， 90^{\circ}$ 方向（10層）含浸における資材の設 置状況を示寸. $0^{\circ}$ 方向含浸では, 写真-1(a)より, 試験 体中央の幅方法から樹脂を投入し，両側から吸引してい る. $90^{\circ}$ 方向含浸では, 写真-1(b)より, 試験体の上部の 長手方向から樹脂を投入し，下部から吸引している. 図 -1では省略しているが，樹脂の含浸補助のため，CFシー 卜5層につき，1層のガラス繊維マット（GM）を挿入し ている. GMは，CFシートに比べて䋊維密度が小さく, 樹脂の含浸を促進する効果があるためである．CFシー 卜の最下層に使用するガラス繊維は，10層の場合，サー フェスマット（SM），15層の場合，チョップドストラ ンドマット（CSM）としている．両繊維ともにガラス 繊維の一種であるが，SMは極めて薄い不織布 $\left(30 \mathrm{~g} / \mathrm{m}^{2}\right)$ である. CSMは短繊維の一方向材をランダムに配置し たものであり，目の粗いマット状の繊維 $\left(300 \mathrm{~g} / \mathrm{m}^{2}\right)$ で ある.これらの繊維はFRP成形時に最外層に配置寸るこ とで，保護層に用いられることが多い．写真-2に，最下 層へのガラス繊維（SM，CSM）の設置状況を示す．SM は薄い不織布の状態であるため, CFシートが見える状 態であるが，CSMはガラス繊維マットが厚いため，ガ ラス繊維がランダムに配置されている状況がわかる.

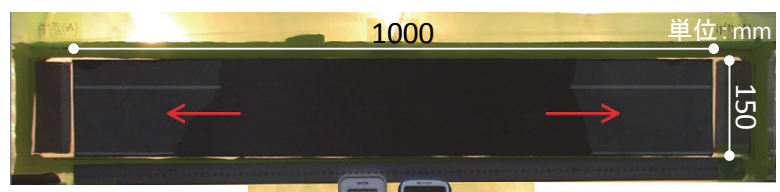

矢印：合浸方向 含浸時間：70分

(a) $0^{\circ}$ 方向含浸 (10層)

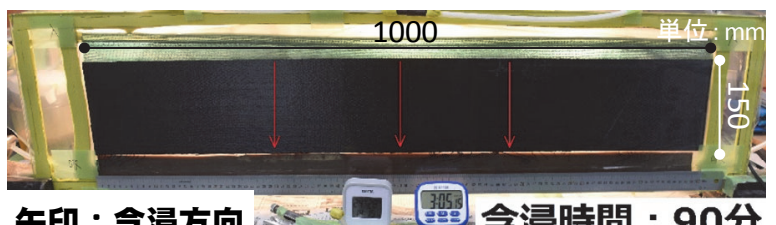

(b) $90^{\circ}$ 方向含浸（10層）

写真-3 ガラス板裏面から観察した樹脂の含浸状況

表-2 含浸施工検討結果

\begin{tabular}{c|c|c|c|c|c}
\hline 含浸方向 & $\begin{array}{c}\text { 積層数 } \\
\text { (ply) }\end{array}$ & $\begin{array}{c}\text { 含浸時間 } \\
\mathrm{T}(\mathrm{min})\end{array}$ & $\begin{array}{c}\text { 含浸面積 } \\
\mathrm{A}\left(\mathrm{cm}^{2}\right)\end{array}$ & $\begin{array}{c}\mathrm{A} / \mathrm{T} \\
\left(\mathrm{cm}^{2} / \mathrm{min}\right)\end{array}$ & $\begin{array}{c}\text { 含浸割合 } \\
(\%)\end{array}$ \\
\hline $0^{\circ}$ & 10 & 70 & 900 & 13 & 60 \\
\hline \multirow{2}{*}{$90^{\circ}$} & 10 & 90 & 1500 & 17 & 100 \\
\cline { 2 - 6 } & 15 & 52 & 1500 & 29 & 100 \\
\hline
\end{tabular}

\section{（2）樹脂の含浸状況の検討結果}

写真-3に，ガラス裏面から観察した最下層（10層）の 樹脂の含浸状況を，また，表-2に，含浸施工の検討結果 を示す，表-2における含浸時間は，樹脂が全面に到達す るまで，あるいは，流動が停止するまでの時間を示して いる，なお，含浸速度は，樹脂の粘度に依存し，施工時 の温度により変化する，施工時の温度は室温で，27〜 $29^{\circ} \mathrm{C}$ であった，含浸面積は，CFシートの最下層まで樹 脂の含浸が確認できた面積を示している．これは，ガラ ス裏面から確認した. 含浸割合は, 最下層全面へ含浸し た場合を100\%とした割合である.

本検討における成形方法では，含浸方向によって含浸 割合に差異が見られ，90方向含浸では含浸割合 $100 \%$ と なり，CFシート全面に含浸することが確認できたが，0 方向の含浸では未含浸部分が確認された.

単位時間あたりの含浸面積 $\mathrm{A} / \mathrm{T} の$ 值は，同一な積層数 である 10 層のケースで比較しても，含浸方向 $0^{\circ}$ で 13 $\mathrm{cm}^{2} / \mathrm{min}$, 含浸方向 $90^{\circ}$ で $17 \mathrm{~cm}^{2} / \mathrm{min}$ であり, 含浸方向を $90^{\circ}$ とした方が単位時間当たりにより多くの面積へ含浸 していることが確認できた，また，90方向でも，SM よ

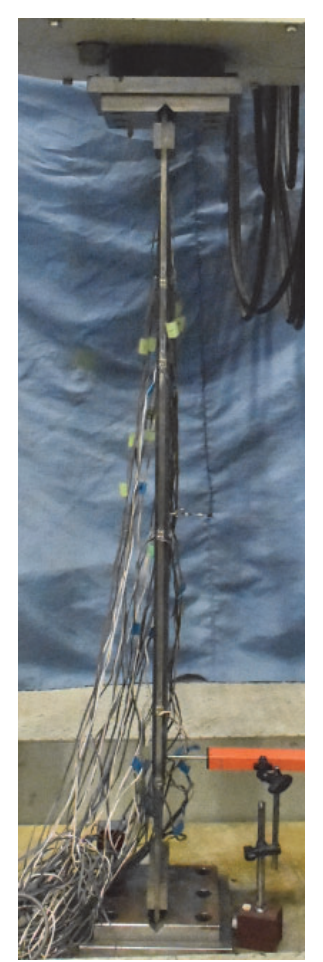

写真-4 セットアップ全体

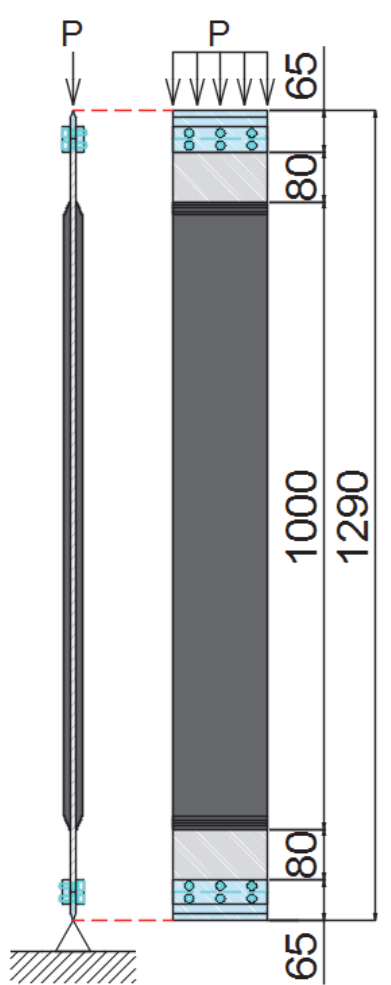

図-2 載荷方法の概念図
表-3 積層 CF シートのパラメータ

\begin{tabular}{c|c|c|c|c}
\hline 積層数 & $\begin{array}{c}\text { 片側の段差 } \\
\text { 長 } l_{s}(\mathrm{~mm})\end{array}$ & $\begin{array}{c}\text { 定着長 } l_{d} \\
(\mathrm{~mm})\end{array}$ & $\begin{array}{c}\text { 有効長さ } l_{e} \\
(\mathrm{~mm})\end{array}$ & $\begin{array}{c}\text { 接着範囲 } l \\
(\mathrm{~mm})\end{array}$ \\
\hline 0 & - & - & - & - \\
\hline 5 & 20 & 35 & 960 & 1000 \\
\hline 10 & 45 & 71 & 910 & 1000 \\
\hline 15 & 70 & 106 & 860 & 1000 \\
\hline 20 & 95 & 131 & 810 & 1000 \\
\hline
\end{tabular}


り繊維密度が小さい CSM の方が, 多積層でもよく含浸 することがわかる．以上の検討結果より，本研究におけ る寸法形状で CFRP を接着する場合，含浸方向は繊維に 対して直角 $\left(90^{\circ}\right)$ 方向とし，CSM を用いることとした。

\section{VaRTM成形で接着された積層CFシートによる 鋼板の座屈耐力の検討}

\section{(1) 試験体とVaRTMlよよるCFシートの接着方法}

試験体には， $150 \times 1200 \times 9 \mathrm{~mm}$ 鋼板（SS400）を用い た。CFシートの接着範囲は， $150 \times 1000 \mathrm{~mm}$ であり， VaRTM成形で鋼板両面に接着することとした．CFシー トの端部には，応力集中を防ぐため，1層ごとに長手方 向5mmのずらして段差を設けることとした.

試験体の表面は黒皮の状態であり，ブラスト面形成動 力工具を用いて下地処理を行った後, プライマー塗布を 行った. 樹脂の硬化後, VaRTM成形により, 所定のCF シートを積層接着した. なお, 下地処理, プライマー塗 布，炭素繊維シートの仮止め，副資材の設置，真空含浸 と養生，副資材の除去後の仕上げについては，後述する 3章 (2)と基本的に同じである. 表-3に，積層CFシートの パラメータを示す．試験体の定着長 $l_{d}$ は，文献7)を参考 に，CFRPの段差部分を無視することで算出した。なお， プライマーの塗布量は重量等で管理を行っていない.

\section{（2）実験方法とセットアップ}

写真-4, 図-2に, 試験体セットアップ時の様子を示す. 圧縮載荷試験では，VaRTMで鋼板に接着されたCFRP部 材による鋼板の座屈耐力を評価するために, 鉛直荷重, 試験体の鉛直変位，水平変位，各部位のひずみを測定し た. 鉛直荷重は $1 \mathrm{~mm} / \mathrm{min} の$ 載荷速度による変位制御によ り載荷を行った. 鋼板の両端に, ナイフエッジの治具を 設置することで，両端ピン支持条件下における座屈試験 を行うものである. 図-3に，ひずみゲージの設置位置の 一例を示す.

\section{（3）座屈荷重の算定と弾塑性挙動の解析条件}

CFシートを接着しない試験体は，オイラーの座屈式 により座屈荷重を算定した。また，CFシートを接着し た試験体の座屈荷重は, 文献7)の「FRP接着長を考慮し た弾性座屈荷重評価法」を参考に求めた。厳密には文献 7)で提案されているように，段差長を考慮する必要があ るが，ここでは，段差長が5mmと短いことから，CFRP の段差を無視し, 有効なCFRPの長さ $l_{e}$ (表-3） は，段差 の部分を除いた長さとし，積層されたCFシートを1枚の CFRP板とみなして，簡易的に座屈荷重を算出した.

さらに，座屈耐力以降の弾塑性挙動を検討するために,

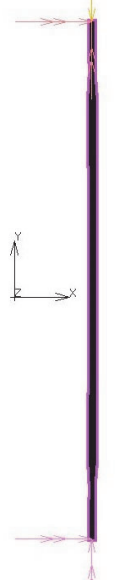

(a) 全体図

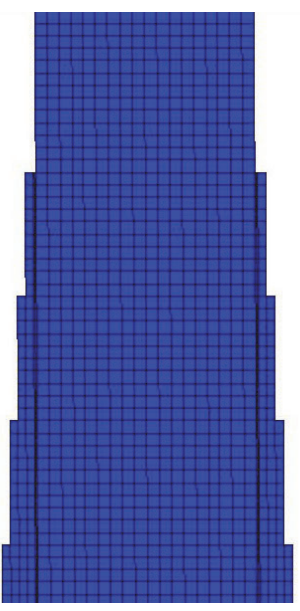

(b) CFRP 端部の拡大図
図-4 解析モデル（5層）

表-4 各部材の材料物性值

\begin{tabular}{|c|c|c|}
\hline \multirow{4}{*}{$\begin{array}{c}\text { 鋼 } \\
(\mathrm{SS} 400)\end{array}$} & 弹性係数 $E_{\mathrm{s}}\left(\mathrm{kN} / \mathrm{mm}^{2}\right)$ & 208.7 \\
\hline & 厚さ $t_{s}(\mathrm{~mm}) ※$ 公称值 & 9 \\
\hline & ポアソン比 $v_{s}$ & 0.30 \\
\hline & 降伏強度 $\sigma_{Y}\left(\mathrm{~N} / \mathrm{mm}^{2}\right)$ & 330.2 \\
\hline \multirow{3}{*}{ CFRP } & 弾性係数 $E_{c}\left(\mathrm{kN} / \mathrm{mm}^{2}\right)$ & 122.5 \\
\hline & 1層当たりの厚さ $t_{d c} V_{f}(\mathrm{~mm})$ & 0.334 \\
\hline & ポアソン比 $v_{c}$ & 0.34 \\
\hline \multirow{3}{*}{ 接着層 } & 弾性係数 $E_{e}\left(\mathrm{kN} / \mathrm{mm}^{2}\right)$ & 5.0 \\
\hline & 厚さ $t_{e}(\mathrm{~mm})$ & 0.1 \\
\hline & ポアソン比 $v_{e}$ & 0.30 \\
\hline
\end{tabular}

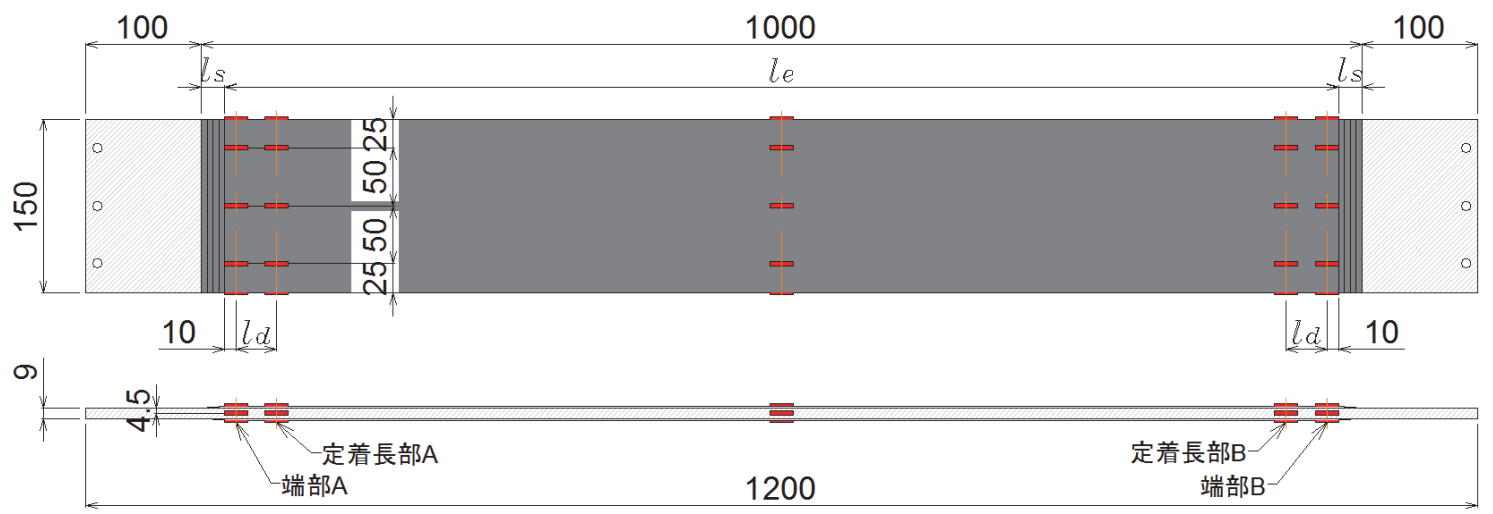

図-3 ひずみゲージの設置位置の一例 
汎用有限要素解析ソフトウェアMarc/Mentat 2013による弾 塑性有限変位解析を行った．解析モデルは，図-4に示す ように，鋼板とCFRPの間に厚さ0.1mmの接着層とCFRP 端部に5mmの段差を考慮し，平面ひずみ要素で作成して， 平面解析を行った．支持条件は，鋼板両端の厚さ中心を ピン支持とした。 また，面外方向に正弦半波の初期たわ み（全長 $L=1290 \mathrm{~mm}$ に対して鋼板中央部にて最大 $L / 500 ）$ を式(1)で与えた．なお， $x, y$ 軸方向は，図-4(a)にある方 向と同一である.

$$
x=\frac{L}{500} \cdot \sin \left(\frac{\pi}{L} \cdot y\right)
$$

数值解析は, 弧長増分法により行い, 最大荷重を求め た. 表-4に，各部位の材料物性值を示す.

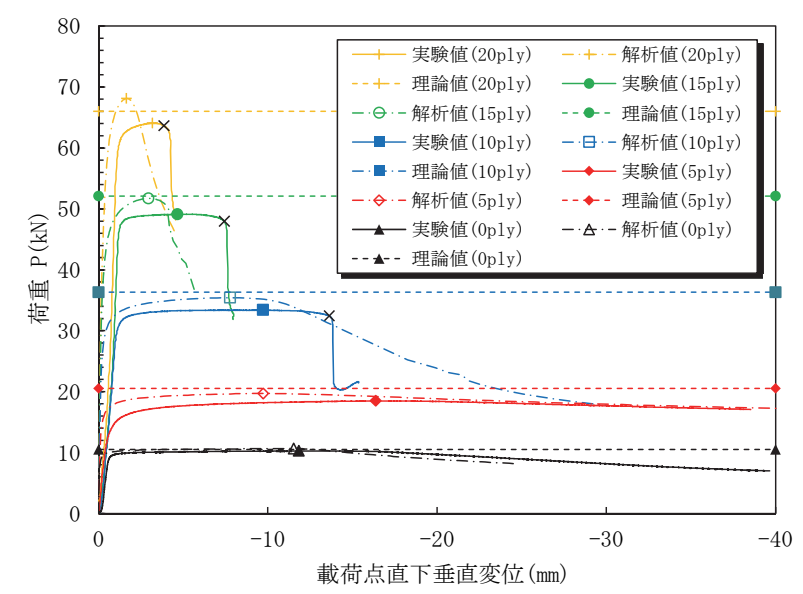

図-5 荷重と載荷点直下の鉛直変位の関係

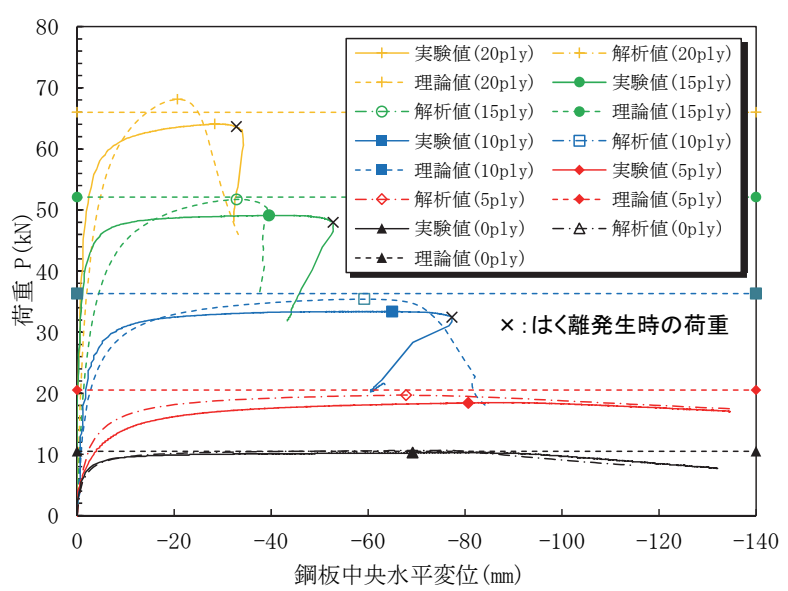

図-6 荷重と試験体中央部の水平変位の関係

表-5 最大荷重の比較

\begin{tabular}{c|c|c|c|c|c}
\hline 積層数 & $\begin{array}{c}\text { 理論值 } \\
P_{a 1}[\mathrm{kN}]\end{array}$ & $\begin{array}{c}\text { 解析值 } \\
P_{\alpha 2}[\mathrm{kN}]\end{array}$ & $\begin{array}{c}\text { 実験值 } \\
P_{\alpha 3}[\mathrm{kN}]\end{array}$ & $P_{\alpha 1} / P_{a 3}$ & $P_{\alpha 2} / P_{\alpha 3}$ \\
\hline 0 & 10.53 & 10.52 & 10.28 & 1.02 & 1.02 \\
\hline 5 & 20.51 & 19.69 & 18.47 & 1.11 & 1.07 \\
\hline 10 & 36.30 & 35.41 & 33.38 & 1.09 & 1.06 \\
\hline 15 & 52.12 & 51.72 & 49.19 & 1.06 & 1.05 \\
\hline 20 & 65.99 & 68.12 & 64.10 & 1.03 & 1.06 \\
\hline
\end{tabular}

\section{(4) 検討結果と考察}

\section{a) 荷重と変位の関係}

図-5に，荷重と載荷点直下の鉛直変位の関係を，図-6 に，荷重と試験体中央部の水平変位の関係をそれぞれ示 す. 図中には，参考值として解析值と理論值を併記し， 実験および解析における荷重の最大值に，積層数別のマ 一カーを記している.

図-5，6より，10層以上の全ての試験体において，最 大荷重以降では，荷重が急激に低下寸ることがわかる. これは，10層以上の全ての試験体において，最大荷重後 にCFRPの端部からはく離が発生したためである。なお, はく離の範囲は端部から50mm程度であった。解析では， はく離の影響を考慮していないが，実験と同様に，最大 荷重後に局部曲げが生じ，荷重が急激に低下する傾向を 示している.

また，図-6より，積層数の増加とともに，はく離発生 までの面外変形量が小さくなることがわかった。これは， CFシートの積層数が多くなると断面剛性が増加し，面 外変形に対する抵抗が増加するためである.

\section{b) 座屈荷重とはく離荷重}

表-5に，座屈荷重の理論值，解析值，実験值を示す. 表より，理論值と実験值の䛊差は2～11\%程度となり， 解析值と実験值の誤差は2～7\%となった．いずれも積層 数が増加するほど，実験值の予測精度が向上する傾向が みられるが，各ケースで試験数が1体と少ないため，そ の理由を示すことはできなかった，FE解析による解析 值の方が理論值よりも精度がよいといえるが，有効長さ leを考慮した，簡便な理論解析においても約 $10 \%$ の精度 で予測できることが確かめられた.

また，図-5，6に併記した，はく離発生時の荷重に着 目すると，はく離は，最大荷重後に発生していることが わかる. なお， はく離は，CFRP 端部の引張側で発生す るため, その箇所のひずみの值が正から負に変化した点 で発生したと判断している.

\section{c) ひずみ挙動}

図-7 に，鉛直荷重時のひずみ挙動の一例として，10

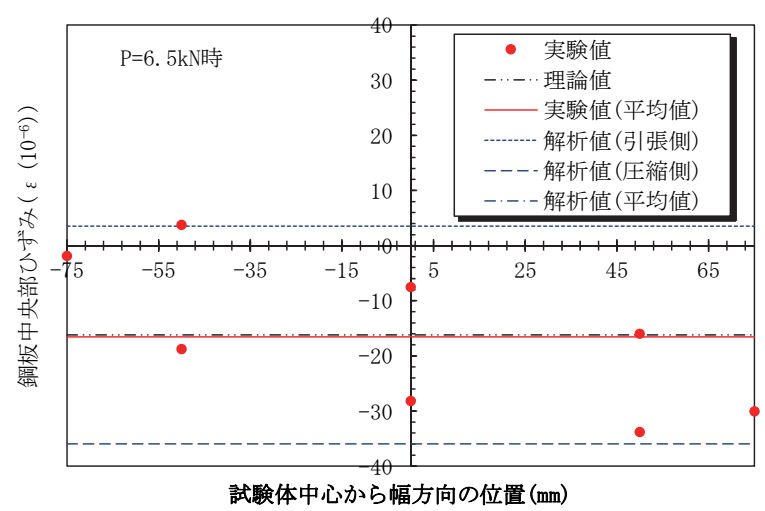

図-7 鋼板中央部のひずみ分布（10層） 
層試験体において，最大荷重の 20\%時の鋼板中央部のひ ずみ挙動の図を示す．評価位置を最大荷重の 20\%時とし たのは，座屈変形にともなって曲げが生じる前の段階に おいて，圧縮力による軸ひずみとして評価をするためで ある，図-7 における理論值とは，鋼と CFRP の合成断面 が一様に圧縮されていると仮定した場合のひずみの值で ある，そのため，実験值は，表裏のひずみの平均值をと

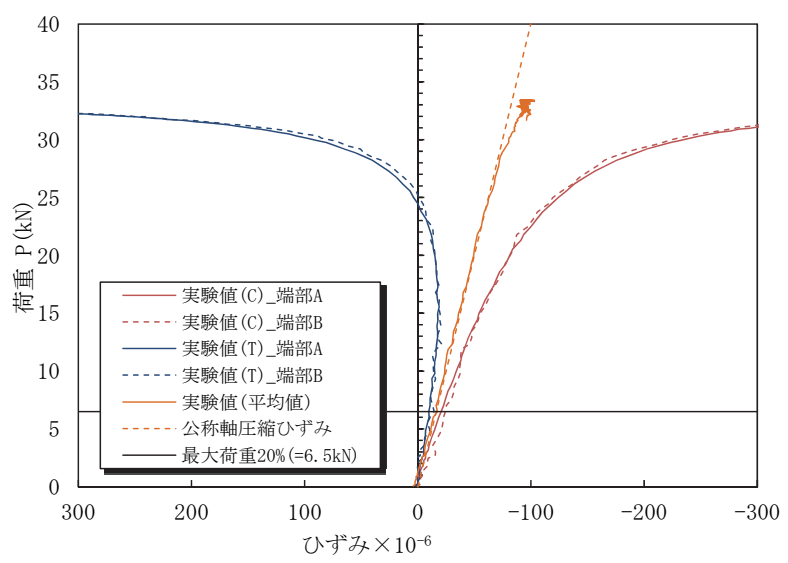

(a) CFRP 端部

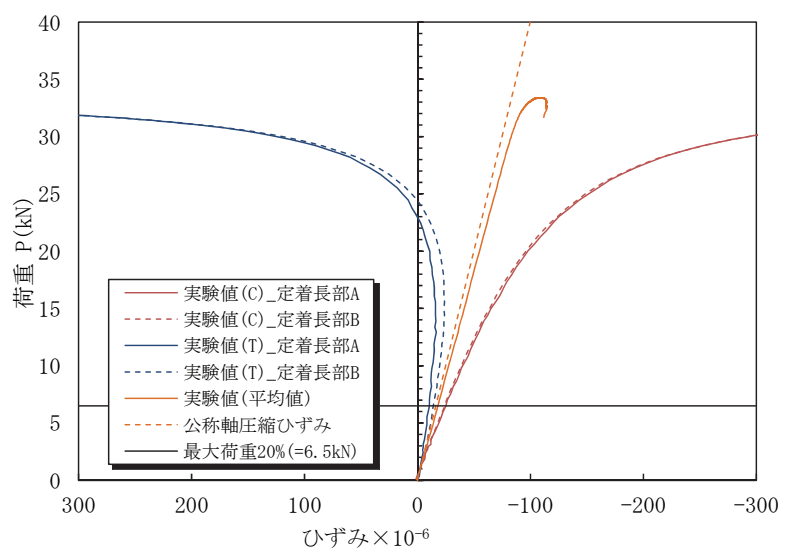

(b) CFRP 定着長部

図-8 荷重とひずみの関係（10層）

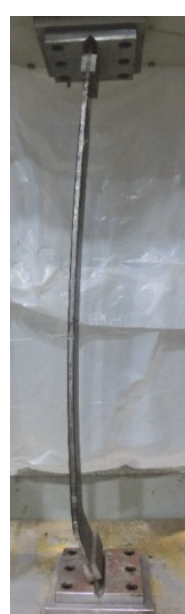

(a) 全体図

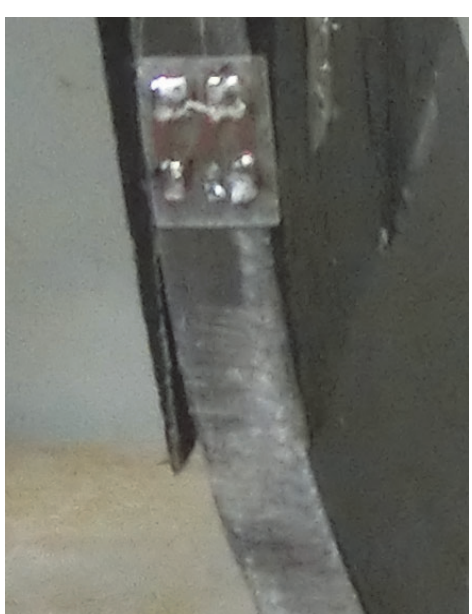

(b) はく離部の拡大図
写真-5 CFRP端部のはく離の発生状況（10層）

ることで曲げによる影響を除去して評価した。一方，解 析值は，FE 解析モデルを平面ひずみ要素で作成したた め，ひずみはそれぞれ幅方向の平均值である. 実験值と 同様に，試験体の表裏で平均值を求め，曲げによる影響 を除去した。

図-7より，実験值（8箇所のひずみの值）は，対称に 分布していないことがわかる。これは鋼板の幅方向に一 様に圧縮が作用していないためである．また，板の面内 曲げによる影響もあることがわかる。

図-8 に，CFRP 端部および定着長部における荷重とひ ずみの関係を示す，C は圧縮側の平均值， $\mathrm{T}$ は引張側の 平均值を示している. CFRP 端部まで応力が伝わり, 全 断面一様に圧縮されると仮定した理論值（公称軸圧縮ひ ず夕）とほぼ一致していることから，応力伝達は CFRP 端部まで十分に行われており，理論計算において段差を 無視して有効長さとする方法は妥当であるといえた.

\section{d) 座屈後の変形挙動}

写真-5に，一例として10層の試験体において試験終了 時, 徐荷前の変形形状とはく離発生部の拡大図を示寸. CFシートの積層数が10層以上の試験体において，座屈 後, CFRPの補強部分と無補強部分の境界でCFRPのはく 離が発生し，局部的に折れ曲がることがわかる．はく離 は，CFRP上下端のいずれか一方のみで発生し，はく離 が発生した端部のみで鋼板が折れ曲がるように，上下非 対称な挙動を示した．また，はく離は10層以上の試験体 全てにおいて，CFRPが引張力を受ける面のCFRP端部で 発生する傾向がみられた。 全体座屈後に, CFRPが接着 されていない部位に塑性変形を伴う局部座屈が生じるた め, 全体座屈後の挙動は理論式の弾性座屈モードを適用 することはできない，なお，5層の試験体では，局部的 な折れ曲がりは生じず，はく離も生じなかった．水平変 位 $130 \mathrm{~mm}$ 程度の範囲では, 変形モードは, 塑性変形を伴 う全体座屈であり, CFRPの破壊も確認されなかった。

一例として, 図-9 に, 10 層モデルにおける最大荷重

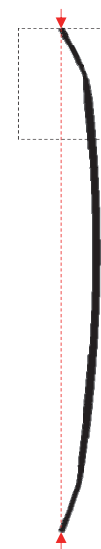

(a) 全体図

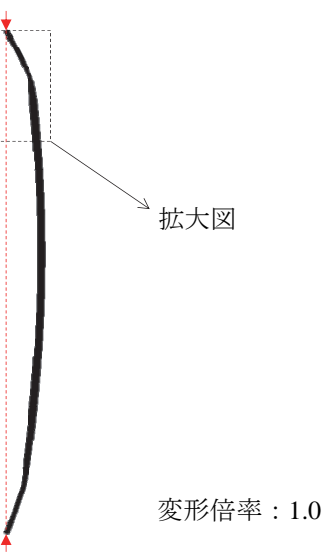

図-9 最大荷重後（20kN 時）の変形図（10層） 
後の変形図（P=20kN）を示す．解析では，はく離を考 慮していないが，実験と同様に，最大荷重後に，CFRP の接着端部で局部曲げが生じていることがわかる.

\section{4. 断面欠損を有する桁端柱部材の性能回復の検討}

\section{(1) 断面欠損のモデル化と試験体}

鋼鈑桁の支点近傍の腐食損傷を補修の対象としている。 表-6 に，試験体寸法を，表-7 に，鋼材（SS400）の材料 特性を示す. 支点上の鈆直荷重に対する柱部材としての 而荷力に着目寸るため，垂直補剛材を含む上下方向に荷 重を載荷するものとしてモデル化した．あらかじめウェ ブ・垂直補剛材下端から $100 \mathrm{~mm}$ の範囲（図-10 のハッチ ング部）で断面欠損を模擬した桁端柱部材を設計した. 板厚の欠損なし（健全体），板厚の欠損率がウェブで 50\%，垂直補剛材で 50\%の試験体，およびより厳しい条 件として，板厚の欠損率がウェブで 50\%，垂直補剛材で 100\%の試験体の3ケース（図-10）で検討した.

（2）CFシートを用いた VaRTMによる補修方法

\section{a) モデル化と補修設計}

補修の方針は，鋼部材の欠損厚さから CFRP の弾性係 数を考慮した等価な剛性を付与することとし, 必要厚さ を算出した．ここでは，積層 CFシートの補修および PF 材による補修の 2 種類を検討寸る．表-8に示すように， 積層補修に用いる $\mathrm{CF}$ シートは高強度タイプであり, こ れまでの VaRTM 成形による施工実績から, 繊維体積含 有率 $V_{f}$ を 50\%とした， 補修の考え方は，「炭素繊維シ 一トによる鋼構造物の補修・補強工法設計・施工マニュ

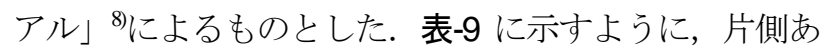
たり，50\%欠損で $9.8 \mathrm{~mm}, 100 \%$ 欠損で $19.6 \mathrm{~mm}$ の CFRP をVaRTM成形により接着することとした。

表-6 試験体寸法

\begin{tabular}{l|c}
\hline 長さ $L(\mathrm{~mm})$ & 300 \\
\hline フランジ幅 $b_{f}(\mathrm{~mm})$ & 270 \\
\hline フランジ厚 $t_{f}(\mathrm{~mm})$ & 20 \\
\hline ウェブ高さ $h_{w}(\mathrm{~mm})$ & 548 \\
\hline ウェブ厚さ $t_{w}(\mathrm{~mm})$ & 12 \\
\hline ウェブ久損部厚さ $t_{w}(\mathrm{~mm})$ & 6 \\
\hline 垂直補剛材幅 $b_{s}(\mathrm{~mm})$ & 130 \\
\hline 垂直補剛材厚さ $t_{s}(\mathrm{~mm})$ & 12 \\
\hline 垂直補剛材欠損部厚さ $t_{s}(\mathrm{~mm})$ & 6 \\
\hline
\end{tabular}

表-7 鋼材（SS400）の材料特性

\begin{tabular}{l|c|c|c}
\hline \multicolumn{1}{c|}{ 項目 } & フランジ & ウェブ & 補剛材 \\
\hline ヤング率 $E_{s}\left(\mathrm{kN} / \mathrm{mm}^{2}\right)$ & 204 & 207 & 206 \\
\hline 降伏強度 $\sigma_{y}\left(\mathrm{~N} / \mathrm{mm}^{2}\right)$ & 300 & 341 & 323 \\
\hline 引張強度 $\sigma_{u}\left(\mathrm{~N} / \mathrm{mm}^{2}\right)$ & 457 & 468 & 456 \\
\hline 伸び $\delta(\%)$ & 33 & 29 & 28 \\
\hline
\end{tabular}

補修範囲は，図-11 に示したように，欠損高さ $100 \mathrm{~mm}$ に対して十分な定着長を確保するため, 高さ方向に 300mm とした. $300 \mathrm{~mm}$ の高さは，一般に，垂直補剛材 に取り付けられるガセットプレートに緩衝しない程度と して設定した.

図-11に，VaRTMによる補修方法と CF シート，PF材 の配置を示す。パラメータは，断面欠損率（50, 100\%），適用する CFRP の形態（積層 CF シート / PF 材），不陸修正の有無であり，それらの組合せで，(a) 〜(d)の 4 ケースを検討する. なお， CF シートの積層数 はウェブ，垂直補剛材の断面欠損量で決定されるが，フ ランジ部は欠損等がないため, CF シートの接着補修は 不要である. しかしながら, 首部に近い欠損部の補強, 柱部材としての円滑な力伝達のために，CF シートを延 長して, フランジ部に定着することとした.

b) 積層 CF シートによる施工方法

写真-6に，VaRTM成形による試験体の補修方法の外 観を，また，写真-7に，積層CFシートによる補修の状況 をそれぞれ示す，標淮的な作業工程は，下地処理，プラ

表-8 CF シート（高強度タイプ）の材料特性

\begin{tabular}{l|c}
\hline 引張弾性係数 $E_{q}\left(\mathrm{kN} / \mathrm{mm}^{2}\right)$ & 245 \\
\hline 引張強度 $\sigma_{q}\left(\mathrm{~N} / \mathrm{mm}^{2}\right)$ & 3400 \\
\hline シート厚さ $t_{q}(\mathrm{~mm})$ & 0.167 \\
\hline 繊維重量 $\left(\mathrm{g} / \mathrm{m}^{2}\right)$ & 300 \\
\hline
\end{tabular}

表-9 CFシートの必要量

\begin{tabular}{|c|c|c|}
\hline 項目 & $50 \%$ 欠損 & 100\%欠損 \\
\hline 鋼材の健全部の厚さ $t_{0}(\mathrm{~mm})$ & 12.0 & 12.0 \\
\hline 鋼材の腐食部の残存厚さ $t(\mathrm{~mm})$ & 6.0 & 0.0 \\
\hline 鋼部材の必要厚さ $t_{s l}(\mathrm{~mm})$ & 6.0 & 12.0 \\
\hline 断面欠損率 $r\left(t / t_{0}\right)$ & 0.50 & 1.00 \\
\hline 鋼材の弾性係数 $E_{\mathrm{s}}\left(\mathrm{kN} / \mathrm{mm}^{2}\right)$ & 200 & 200 \\
\hline CF シートの弾性係数 $E_{q}\left(\mathrm{kN} / \mathrm{mm}^{2}\right)$ & 245 & 245 \\
\hline 繊維体積含有率 $V_{f}(\%)$ & 50 & 50 \\
\hline 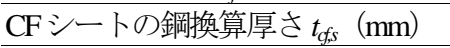 & 4.9 & 9.8 \\
\hline CFRP としての厚さ $t_{\text {qs,sf }}(\mathrm{mm})$ & 9.8 & 19.6 \\
\hline CF シートの積層数 $n$ & 30 & 60 \\
\hline
\end{tabular}

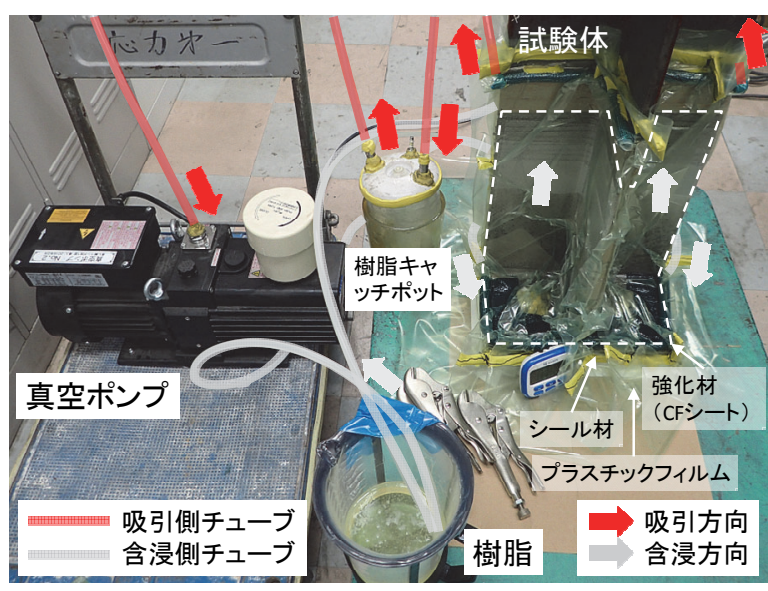

写真-6 VaRTM成形による試験体の補修方法の外観 ${ }^{6}$ 
イマー塗布，不陸修正（有無の検討），CFシートの仮 止め, 副資材の設置，真空含浸の手順であり，各工程の 概要を以下に示す.

下地処理については，試験体の表面は黒皮の状態であ り，欠損範囲は切削加工のため，素地状態である．現場 施工を想定して，屋外暴露により久損範囲を赤錆状態と した. 下地処理には，ブラスト面形成動力工具とディス クサンダーを用いて錆や黒皮などを除去した. その後, アセトンを用いて表面を清掃し，油分や污れのない状態 とした（写真-7(a)）。

下地処理後の鋼材表面の錆防止と炭素繊維シートとの 接着性を向上させるために，プライマー（AUP40）を塗 布した. プライマーの塗布は，鋼材表面に錆の発生や污 れがないように，下地処理後，速やかに行った，プライ マ一塗布後, 投光器を用いて約 $40^{\circ} \mathrm{Cで} 24$ 時間養生を行 った（写真-7 (b)）。なお，本実験では，樹脂の硬化の 促進と確実な硬化状態とするために，加温養生を行って いる. 用いた含浸接着樹脂は常温硬化型であるため, 現 場では，10C以上であれば，施工・養生は可能であり， 加温養生等, 特殊な養生は必要ない.

不陸修正については，エポキシ樹脂のパテ（AUF60）
を用いて，鋼材の表面を平坦に仕上げた。すみ肉溶接の コーナ一部（入角部）は樹脂パテで，溶接ビード部が隠 れるように仕上げた。養生条件は約 $40^{\circ} \mathrm{C} ， 24$ 時間とし た. その後の工程は, 樹脂の指触乾燥の確認後に行った (写真-7 (c)) .

アンカーボルトへ樹脂が侵入しないようにするため, また，ボルト孔から空気が漏れることを防ぐために，ボ ルト周辺をシーラントテープで養生した（写真-7 (d)）.

CF シートは一方向材であり，配向方向は，ウェブ， 垂直補剛材の高さ方向とした. 鋼材との接触面, 所定の 積層数に樹脂リッチ層を設けるため, SM を, 初層（鋼 材と CF シートの間) に，CF シートを 5 層積層するごと に挿入した。 また，ウェブ側，垂直補剛材の端部には， CF シートに段差を設けるために，2 層目から，久損率

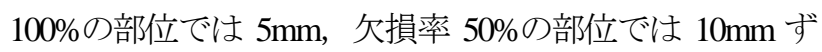
つずらして仮止めを行った（写真-7 (e)）. 本研究では, 段差の全長を揃えるために，久損率ごとにずらし量を変 えている.

硬化後に資材の取り外しを容易にするため，最外層の CF シートには，はく離シート（ピールプライ）を設置 した. 次に，樹脂の流動性を確保するために，樹脂拡散

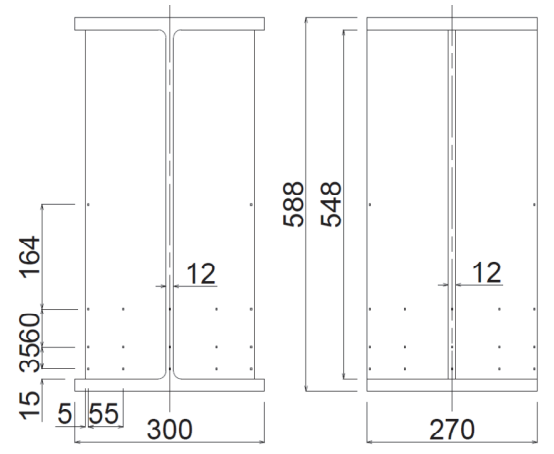

(a) 健全体

(W000V000)

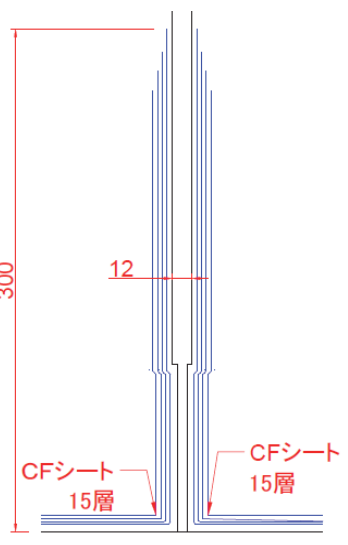

(a) $50 \%$ 欠損，不陸修正無
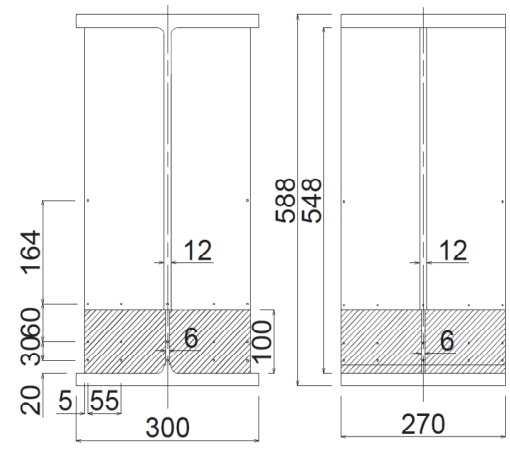

(b) ウェブ 50\%，垂直補剛材 50\%欠損

(W050V050)
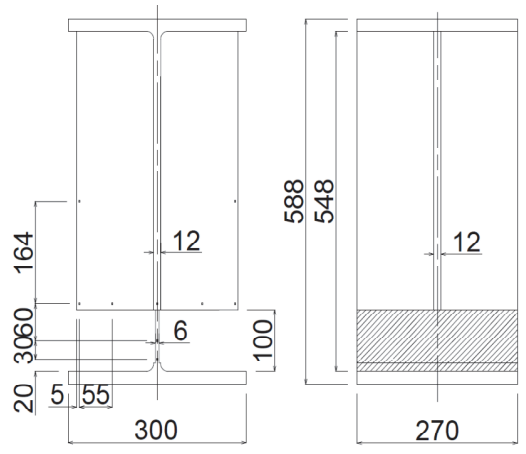

(c) ウェブ 50\%, 垂直補剛材 100\% 欠損 (W050V100)

図-10＼cjkstart桁端柱部材のモデル化とひずみゲージ位置

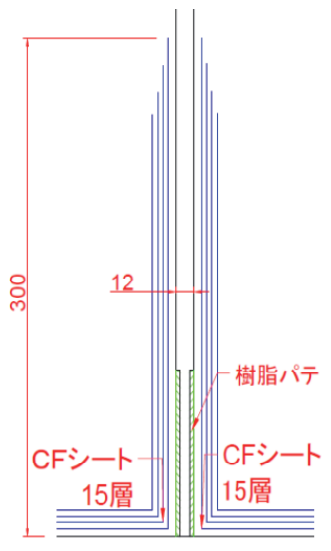

(b) 50\%損，不陸修正有

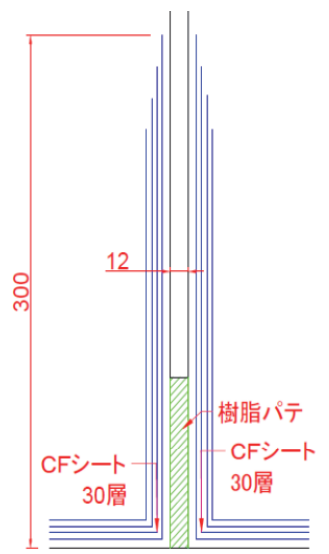

(c)100\%欠損，不陸修正有

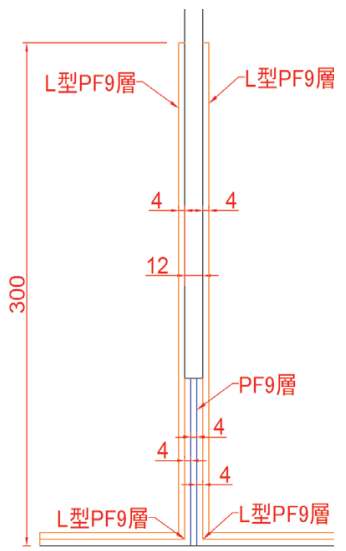

(d) $100 \%$ 欠損, PF材

図-11 VaRTMによる補修方法とCFシート，PF材の配置の概念図 
メディアを 3 層設置した（写真-7 (f)）。樹脂の含浸範囲 をシーラントテープで囲った後，樹脂含浸用パイプを下 フランジ側に, 吸引用パイプ 2 本を上側の CF シート端 部にそれぞれ設置して，それらをバギングフィルムで封 入した (写真-7 (g)) .

真空ポンプを用いて吸引する際，十分な真空度が確保 されていることを確認後，樹脂引き用パイプから含浸接 着樹脂（AUP40）を吸引した，真空含浸は，補修箇所 4 箇所のうち，2 箇所を同時に行った. 樹脂の含浸の完了 後, パイプの端部をバイスプライヤーで締め切り, 硬化 するまで養生した，十分に硬化させるため，養生条件は 約 $40^{\circ} \mathrm{C} ， 24$ 時間とした. なお，含浸接着樹脂は，プラ イマーと同じ， 2 液性常温硬化型エポキシ樹脂である. 樹脂の粘度は $7.0 \sim 12.2 \mathrm{dPa} \cdot \mathrm{s}$ で行った. 真空吸引による 含浸時間は，樹脂の可使時間内（約 1 時間）とした（写 真-7 (h)）。最大積層数は 60 層であり，この時の含浸時 間は 50 分であった。

バギングフィルム，ピールプライ等の副資材の除去後, 硬化した余分な含浸接着樹脂は, スクレーパー, ディス クグラインダーを使用し，仕上げを行った．このとき， 硬化した CFRP に損傷を与えないように留意した（写真 -7(i).さらに, ボルト周辺の余分な CFRPを除去し, 仕 上げた.

\section{c) プリフォーム材による施工方法}

写真-8 (a)に，含浸前のPF材を示す．PF材を用いた補 修では, CF シートは中弾性タイプ（シートの厚さ
$0.217 \mathrm{~mm}$, 引張強度 $2.4 \mathrm{kN} / \mathrm{mm}^{2}$, 弾性係数 $440 \mathrm{kN} / \mathrm{mm}^{2}$ ) を 用いた. 中弾性タイプは, 強度と弾性係数のバランスに 優れ，弾性係数が高い CF シートの中でも取り扱い時や 加工時に損傷しにくいこと，また，䋊維体積含有率 $V_{f}$ が 50\%であれば，硬化後の CFRP の弾性係数と厚さは鋼 材とほとんど等価となるため，設計，施工上，取り扱い やすいという特徵がある．PF材の積層数は，図-11 (d)に 示したように， 9 層とした. これは PF 材を機械加工す るための $\mathrm{PF}$ 試作機の仕様として，CF シートの供給数が 最大 9 層までとなっているためである. PF 材の積層構 成については，一方向 CF シート 8 層の中央に, 二方向 CF シート 1 層を配置している. 中央に二方向 CF シート を入れることで, PF 材の幅方向に剛性が付与されるた め, 写真-8 (a)に示寸ように, PF 材が自立し, 形状保持 するようになる．なお，断面当たりの機械性能が落ちる ため，PF材には，CSMを入れていない．

さらに，PF材に用いた CF シートには，熱可塑性樹脂 材を粒子状に加工したもの（写真-8 (b)）が散布されて

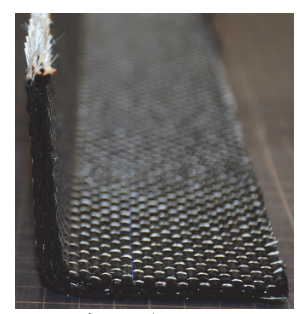

(a) 含浸前のPF材 (b) 表面の粒子散布

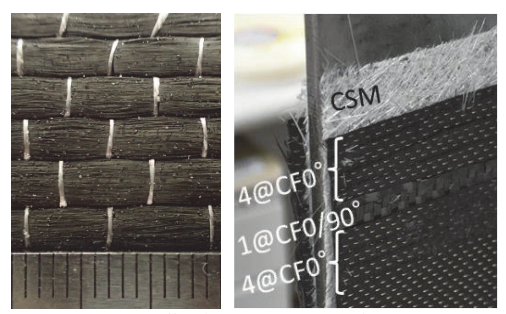

(c) 段差の設置
写真-8 プリフォーム材による補修の状況

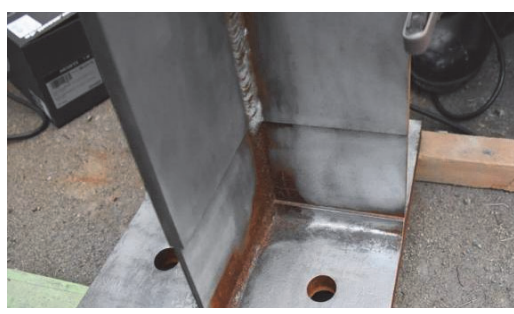

(a)下地処理

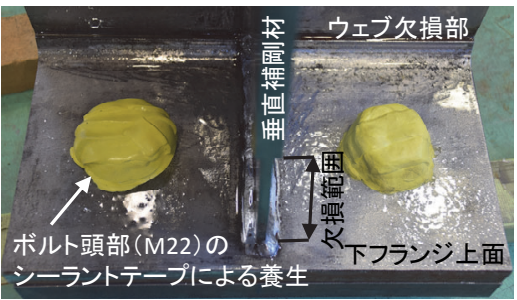

(d) ボルトの養生

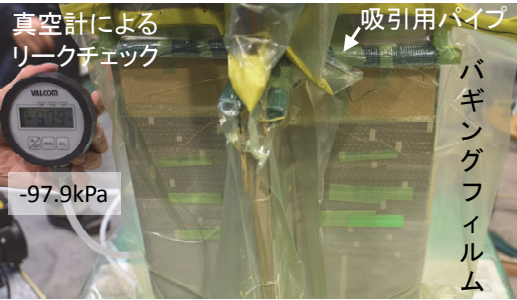

(g)バギングフィルムの設置と真空化

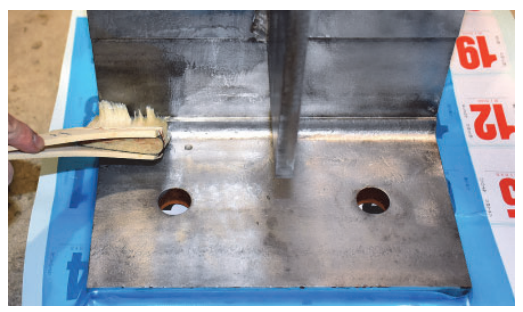

(b) プライマー塗布

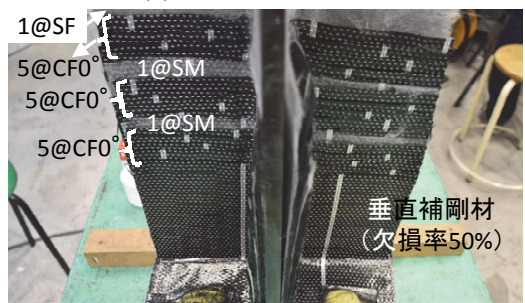

(e)CF シートの仮止め

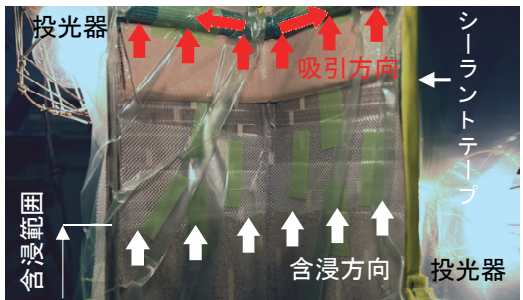

(h) 真空含浸の状況

写真-7 積層CFシートによる補修の状況

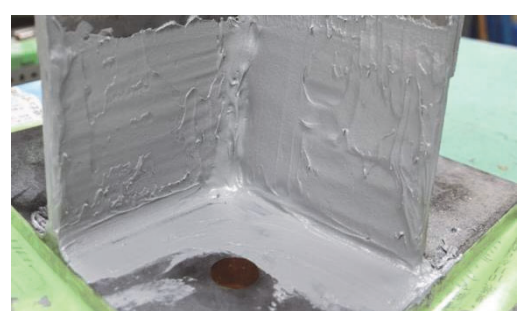

(c) 不陸修正

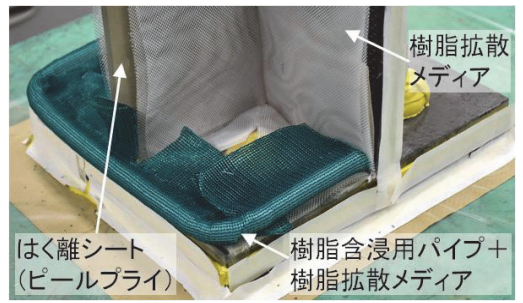

(f)副資材の設置

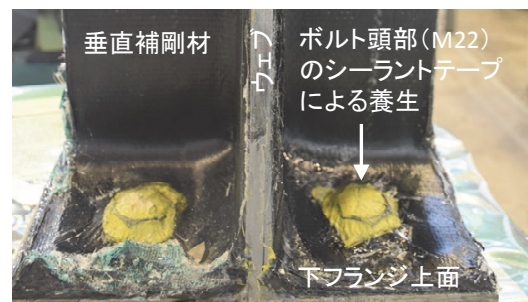

(i) 資材を取り除いた後の状況 

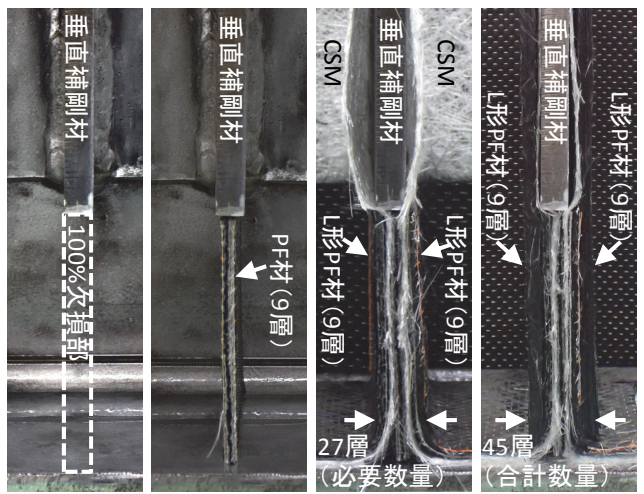

(a) 欠損部 (b) PF材9層 (c) PF材27層 (d) PF材 45層

写真-9 欠損率 100\%部位へのプリフォーム材の 配置方法

おり，熱を与えて溶融させることで CF シート間を仮固 定して形状を保持している．欠損率 100\%の部位への PF 材の配置について, 図-11(d), 写真-9 に概要を示す。ま ず，久損率 100\%の部位（写真-9 (a)） へ，平面状の 9 層 の PF材（写真-9 (b)）を充填し，L形 PF材を両側から当 てること（写真-9 (c)）で補修に必要な数量（27 層） と なるが，はく離防止のため，さらに最外層に L 形 $\mathrm{PF}$ 材 を配置（写真-9 (d)）し，合計 45 層としている．施工方 法は，積層 CF シートが PF 材に置き換わることのみで あり，写真-7 に示した施工方法と同じである. なお，

写真-8 (c)に示すように，PF材の端部にも CF シートと同 様に段差を設けている．PF材を用いることにより，1層 ごとに CF シートを積層して設置する場合（約 1 時間／ 箇所）に比べて, 約 5 分/箇所となり, CF シートの設 置時間を大幅に短縮することができた.

\section{（3） 実験方法}

図-12 に，セットアップ図を，写真-10 に，セットア ップの状況を示す．試験体の上下面にソールプレート

（300×270mm）をボルトで固定した。鋁直荷重の載荷に は, 油圧ジャッキ（最大荷重 $2,000 \mathrm{kN}$, 最大ストローク 200mm）を用いた．図-12 に示したように，荷重はジャ ッキ下端のロードセルにより，鉛直変位は上面の載荷板 の4箇所に設置した変位計により計測した．鉛直変位は 4 箇所の平均值とした.ひずみゲージはウェブ・垂直補 剛材端部（健全体は下端から $15 \mathrm{~mm}$, 無補修モデル・ W050V050 の補修モデルは 20mm，W050V100 補修モデル は 30mm）に配置したモモデルによって配置が違うのは CFRP の厚さが大きくなり，ひずみゲージが配置できな くなったためである. また，ウェブと垂直補剛材の下端 から 50，110mmの位置にひずみゲージを配置した。

\section{(4) 実験結果と考察}

a) VaRTM 成形による CFRP の含浸接着の状況

断面欠損した試験体（4 体）に，VaRTM 成形によっ

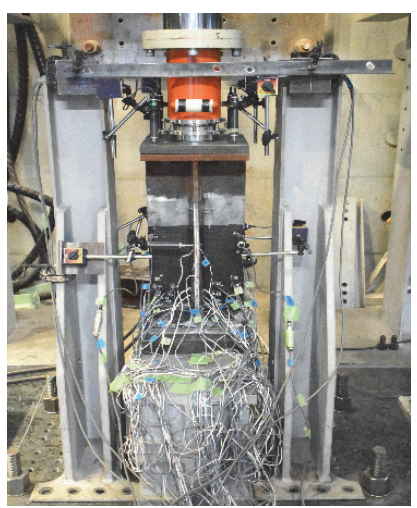

写真-10 セットアップの状況
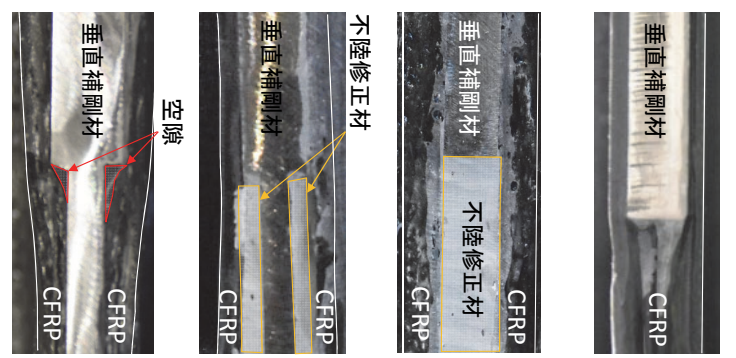

(a) W050V050RN (b) W050V050RE (c) W050V100RE (d) W050V100PN 写真-11 CF シート, PF材の積層による欠損部の補修の状況

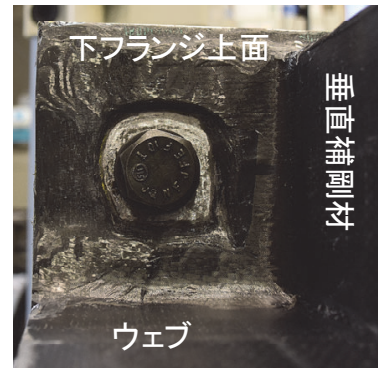

(a) $\mathrm{CF}$ シート

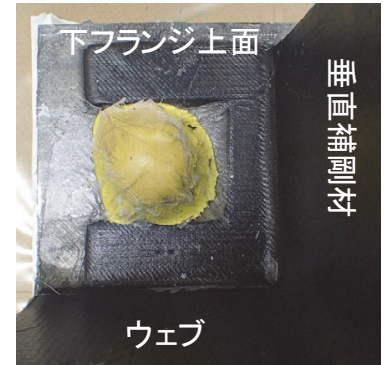

(b) PF材
写真-12 アンカーボルトの回避の状況

て CFシート，PF材をそれぞれ含浸・接着した．その含 浸状態を打音検査で確認したが，未含浸，ボイド等の異 常は検出されなかった. また，写真-11に，CF シート， $\mathrm{PF}$ 材の積層による欠損部の補修の状況を示寸，不陸修 正がない W050V050RN（写真-11 (a)）では，直角の入隅 部に CF シートが追従できずに CF シートに曲がりが生 じ，空隙が生じていること，欠損部を樹脂パテで不陸修 正した W050V050RE（写真-11 (b)）, W050V100RE（写 真-11 (c)）には，空隙が生じていないことがわかる，さ らに，久損率 100\%の補剛材を PF材で充填して含浸接着 した W050V100PN（写真-11 (d)）からは，CFシート積層 の場合と比べると, 形状が安定して, 品質が向上してい ることがわかる.

写真-12 に，アンカーボルトの回避の状況を示す．PF 材では，ボルト頭部（M22）にシーラントテープで養生 している状況を示している. 写真より, CF シート, PF 材ともに，アンカーボルトを回避して，VaRTM 成形に より，含浸，接着ができることがわかる．また，PF 材 
では，アンカーボルトまわりの排水に配慮して，CFRP に切り欠きを設けている.このように，PF 材であって も予め加工を施すことで，簡便かつ柔軟に対応できるこ とがわかる。

\section{b) 耐荷力と性能回復の状況}

図-13 に，荷重と載荷点直下の鉛直変位の関係を，表10 に，各モデルの最大荷重と補修効果をそれぞれ示す

まず，無補修の W050V050 と W050V100の而荷力は, 健全体（W000V000）と比べ，それぞれ 46\%，75\%低下 した.これは，後述するようにウェブと垂直補剛材の欠 損部において早い段階で降伏し，局部座屈が生じたため である。

一方，不陸修正を施して補修した W050V050RE では， 健全体モデルに比べて，柱部材としての最大荷重は $1 \%$ 高くなり，剛性も初期性能まで十分に回復していること， また，不陸修正なしで補修した W050V050RN では，剛 性，耐荷力ともに初期性能まで回復しないことがわかる. さらに，不陸修正を施して補修した W050V100RE では， W050V050RN と同様に，十分に回復しなかった。これは， W050V050RN では，写真-11 (a)に示したように，不陸修 正がないため，欠損部で CFRP に局部的な曲がりが生じ て，弱点となったこと，W050V100RE では，欠損率 100\%の断面欠損部は，不陸修正され，必要な剛性を CFRP で補っているが，樹脂充填のみであったため, CFRP の座屈も要因として考えられる. これに対して,

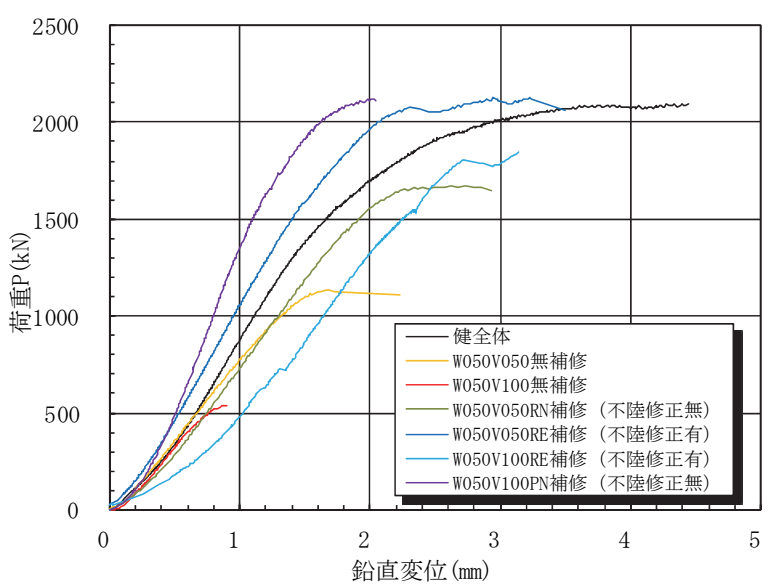

図-13 荷重と載荷点直下の鉛直変位の関係

表-10 各モデルの最大荷重と補修効果

\begin{tabular}{|c|c|c|c|c|}
\hline モデル名 & 状態 & 不陸修正 & $\begin{array}{l}\text { 最大荷重 } \\
P_{\text {max }}(\mathrm{kN})\end{array}$ & $\begin{array}{c}\text { 健全体に対 } \\
\text { する割合 }\end{array}$ \\
\hline W000V000 & 健全 & - & 2097.2 & 1.000 \\
\hline W050V050 & \multirow{2}{*}{ 無補修 } & - & 1135.6 & 0.541 \\
\hline W050V100 & & - & 533.8 & 0.255 \\
\hline W050V050RN & \multirow{4}{*}{ 補修 } & $\begin{array}{l}\text { 無 } \\
\end{array}$ & 1670.0 & 0.796 \\
\hline W050V050RE & & 有 & 2126.5 & 1.014 \\
\hline W050V100RE & & 有 & 1845.9 & 0.880 \\
\hline W050V100PN & & 無 & 2117.8 & 1.010 \\
\hline
\end{tabular}

欠損率 $100 \%$ の断面欠損部に PF 材を充填して補修した W050V100PN では，最大荷重が健全体と同レベルまで回 復していることがわかる。ただし，CFRP で補修した試 験体 W050V050RE，W050V100PN の最大荷重は，健全体 と同レベルまで回復するものの，最大荷重時の変形が小 さく, 破壊性状は脆性的であることから変形性能を求め る場合には注意が必要である。

\section{c) ひずみ挙動}

図-14 に，荷重とウェブの軸ひずみの関係を，図-15 に，荷重と垂直補岡材の軸ひずみの関係を高さごとにそ れぞれ示す。軸ひずみは，同じ高さの位置のひずみゲー ジの值を平均して算定している．また，軸圧縮力を受け る柱部材の一般的な挙動として, 健全体のウェブ, 垂直 補岡材の断面が降伏する時を降伏耐力として併記してい る. 降伏耐力, 降伏ひずみは，表-7 に示した，各部材 の降伏強度，ヤング率の平均值から算定している.

図-14 (a)，(b)より，欠損部について，まず，無補修の は，W050V050 と W050V100は，降伏ひずみ（約 1600× $\left.10^{-6}\right)$ に達する荷重が小さいことから，欠損部が早い段 階で降伏していることがわかる。これに対して，補修モ デルは，無補修と比べ，大幅にウェブの軸ひずみが抑制 されていることがわかる。下端から 50 mm位置の軸ひず みは，W050V050RE，W050V100PN では，ひずみは，最 大荷重付近までウェブ, 補岡材ともに直線的に増加し, 最終的に健全体よりも軸ひずみが抑制されることがわか る. W050V100RE においても，ひずみは最大荷重付近ま でほぼ直線的に増加し，健全体よりも抑制されるものの， 最大荷重付近で急激に不安定となり破壊している。一方， W050V050RN では，同様にひずみは抑制されるものの, $1300 \mathrm{kN}$ 付近からひずみが増加し, 而力が低下した。

また，下端から 110mm 位置において，W050V050RN では 700〜 1670kN で軸ひずみが不規則な挙動を示してい る.これらより，不陸修正を行わなかったモデルは，軸 方向に十分に荷重力が伝達されていないといえる.

これらの傾向は, 図-15 示した，垂直補剛材の軸方向 ひずみからも同様の傾向にあることがわかる．なお，不 陸修正を施して補修した W050V100REでは，図-15 (a), (b)より, 樹脂が充填された位置では，ひずみ挙動は図14 (a), (b)のウェブ (欠損率 50\%の部位に樹脂を充填して CFRP接着している)のひずみ挙動と比べて不安定である ことがわかる，充填した樹脂の弾性係数は，CFRP，鋼 材に比べて $1 / 50$ 程度と相対的に小さいため, 面外方向 に変形を許容しやすい. その結果として，CFRP の座屈 等も一因として考えられた。

\section{d) 座屈挙動}

図-16 に，はく離したウェブの CFRP 端部の荷重と軸 ひずみの関係を，写真-13に，試験体の座屈変形をそれ ぞれ示す．健全体は，全断面の塑性後に，上部に局部座 


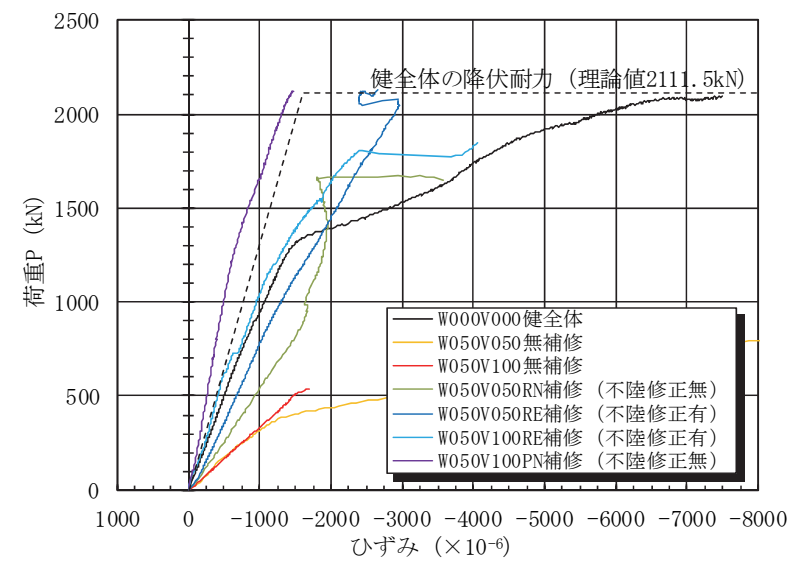

(a) ウェブ下端から 15，20，30mm の高さ

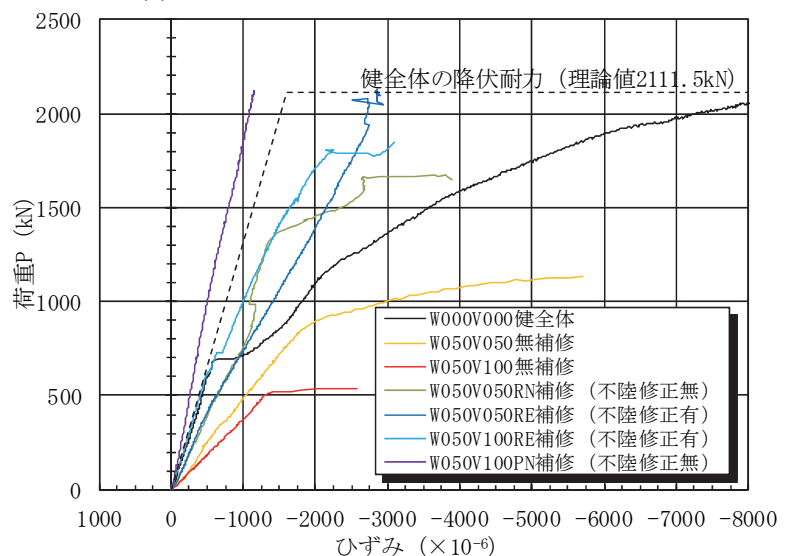

(b) ウェブ下端から 50mm の高さ

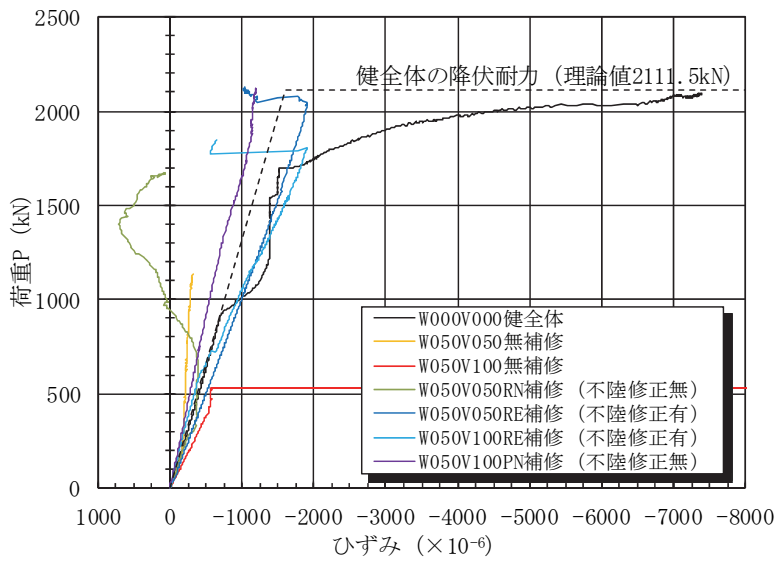

(c) ウェブ下端から $110 \mathrm{~mm}$ の高さ

図-14 荷重とウェブの軸ひずみの関係

屈が生じた．この理由として，上端にはロードセルの回 転機構があり，回転に対して拘束が小さいためと考えら れる.すべての補修モデルでは，欠損部で，CFRP のは く離が生じ，局部座屈が生じた．健全体まで而荷力が回 復していないモデル W050V050RN では $1400 \mathrm{kN}$ 付近,

W050V100RE では $1100 \mathrm{kN}$ 付近ではく離が生じた. この ことから CFRP のはく離は，最大荷重に大きな影響を与 えることがわかる.

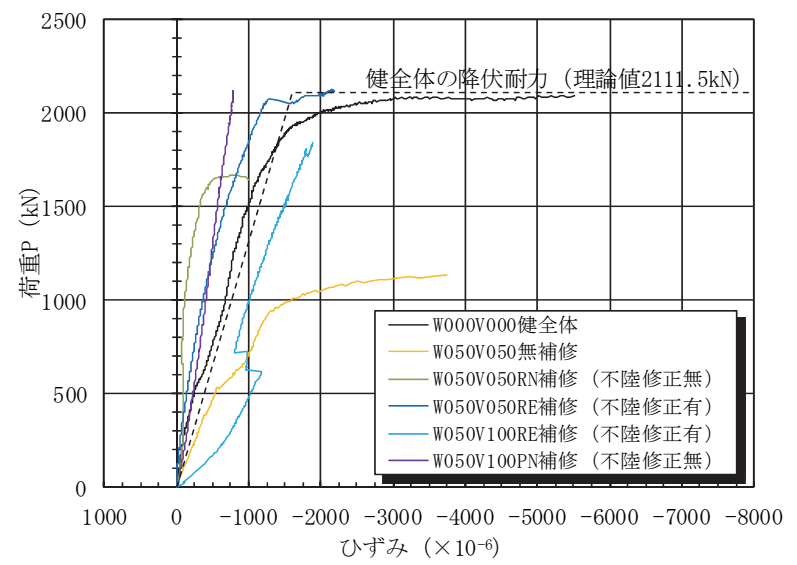

(a) 補岡材下端から 15，20，30 mm の高さ

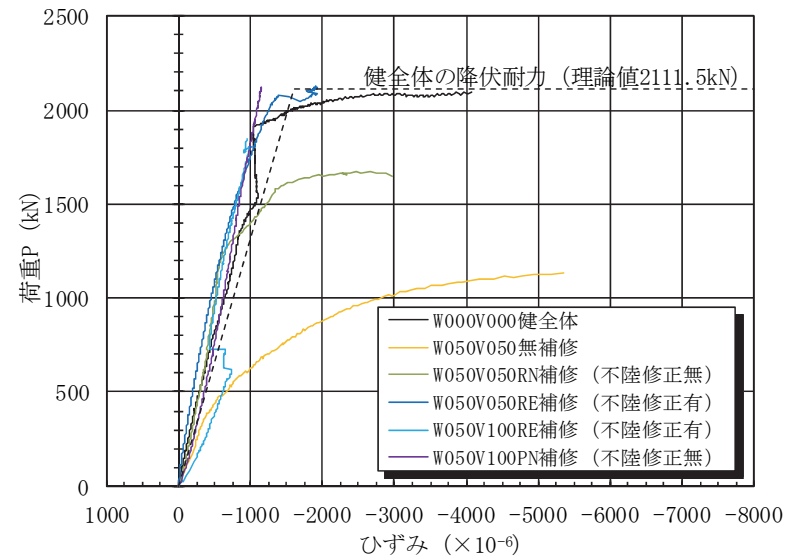

(b) 補岡材下端から $50 \mathrm{~mm}$ の高さ

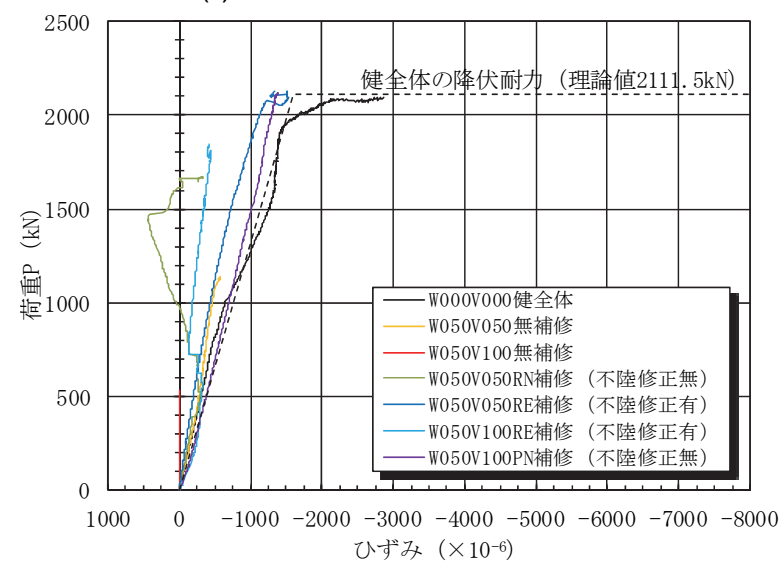

(c) 補岡材下端から $110 \mathrm{~mm}$ の高さ

図-15荷重と補剛材の軸ひずみの関係

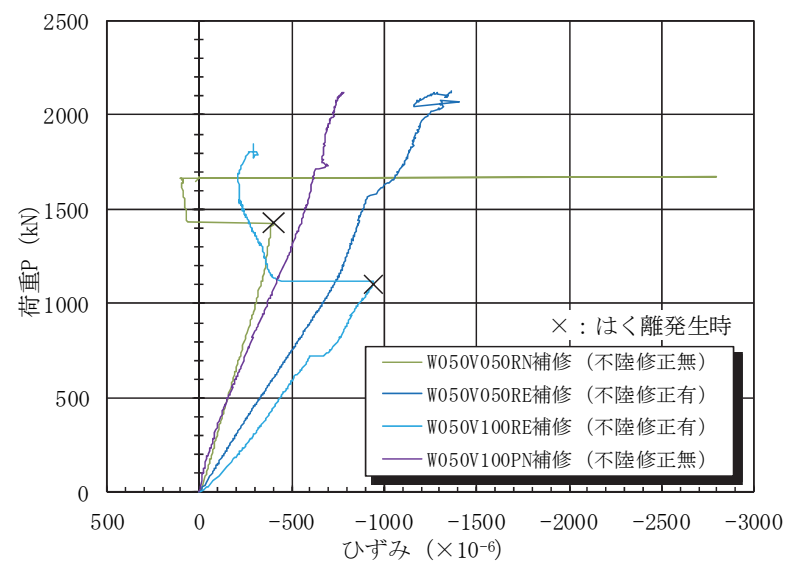

図-16 ウェブの CFRP端部の荷重と軸ひずみの関係 


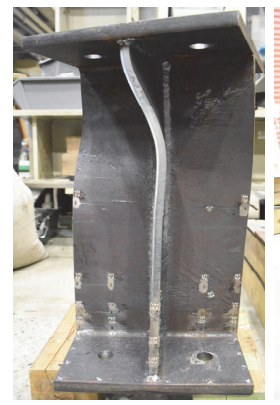

(a) W000V000

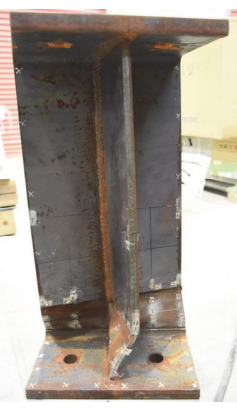

(b) W050V050

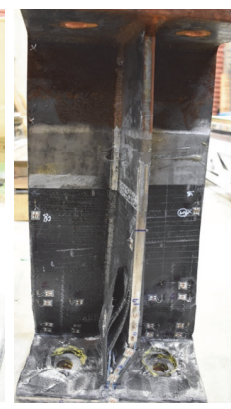

(c) W050V050RN

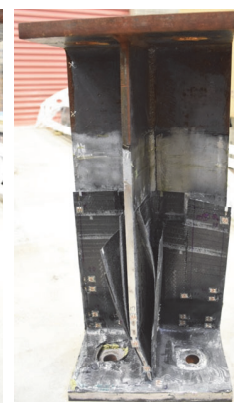

(d) W050V050RE

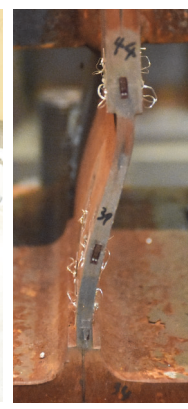

(e) W050V100

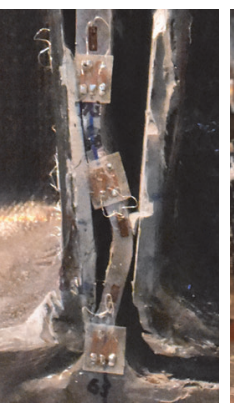

(f) W050V100RE

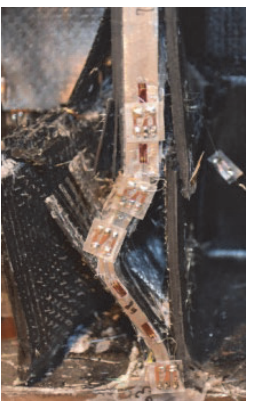

(g) W050V100PN

写真-13 試験体の座屈変形

\section{5. まとめ}

本研究では，VaRTMによる多積層のCFシートの含浸 方法を検討するとともに，多積層CFシート接着による 補強効果を検証するために，CFRPが接着された鋼板の 座屈実験を行った，それらの結果，次のことがいえた.

(1) 多積層CFシートでVaRTMを行った結果，含浸方向 を䋊維直角方向とし，含浸距離を短くすることで, 多積層CFシートの最下層まで樹脂を含浸させるこ とが可能であることが確かめられた。

（2）支持間隔に対して $77.5 \% の$ 範囲を，5mmの段差を設 けてCFシートを積層接着した場合, 最大荷重まで はく離しないこと, はく離は無補強部の局部曲げ によることから，座屈補強に有効であるといえた

(3) CFRP部材が接着された鋼板において，段差を無視 することで簡易的に算出した座屈荷重の理論值は, 実験值に対して約10\%の精度で座屈荷重を予測で きること，FE解析モデルで段差を考慮すれば数\% の精度で座屈荷重を予測できることがわかった。

（4）CFシートを10層以上とした場合，CFRP端部ではく 離が発生し，その位置で鋼板が局部的に折れ曲が る挙動を示した，FE解析では，はく離を考慮して いないが，実験と同様の変形モードであった。

さらに, 鋼鈑桁橋の桁端腐食部を対象に, VaRTM 成 形を応用した CFRP 部材による桁端柱部材の而荷力の回 復について，実験的な検討を行った。 その結果，以下の ことがいえた。

(5) 最大積層数 60 層に対して, VaRTM では約 50 分で CF シートへの含浸が完了したこと，アンカーボル トがある場合にも回避して含浸接着が可能である ことが確かめられた。

（6） $50 \%$ 欠損では，不陸修正を行って CFRP 接着するこ とで, 而荷力, 剛性は, 初期性能まで回復するこ とが確かめられた。

（7）不陸修正を行わない場合，CFRP の不連続部を起点 としたはく離が生じること，また，100\%欠損で不 陸修正を行っても CFRP のはく離が先行すること
により，而何力は初期性能まで回復しなかった.

（8） PF材を用いた補修は，CF シートを積層する場合に 比べ，CF シートの設置時間が大幅に短縮可能とな ること, また, 而何力, 剛性ともに初期性能まで 回復することが確かめられた.

以上のことから，圧縮力を受ける鋼部材に対して， VaRTM 成形を応用した CFRP 部材による補修・補強が 有効であることが確かめられた．本工法を現場へ適用す るにあたっては，プラスチックフィルムで密閉して真空 化する工程等, 従来の工種にはない作業が含まれること から，技術の習得が必要である．また，今回は，実験室 レベルでの検討であるため，各工程の時間等を管理，計 測していなかった，現場での試験施工を，別途，実施し ているため, 施工方法については, 改めて報告したい. 本工法の普及, 標準化にあたっては, 今後, 施工マニュ アル等を整備する予定である.

謝辞 : 本研究は, 平成 27 28 年度国土交通省建設技術 研究開発助成制度の一部として行われた。ここに記して 謝意を表します。

\section{参考文献}

1) 国土交通省国土技術政策総合研究所：道路橋の部分 塗替え塗装に関寸る調查研究，国土技術政策総合研 究所資料, 第 1 章, 第 684 号, 2012.4

2) 国土交通省国土技術政策総合研究所：道路橋の局部 腐食に関寸る調查研究, 国土技術政策総合研究所資 料，第 294 号，2006.1

3) 複合構造委員会編：FRP 接着による鋼構造物の補 修・補強技術の最先端, 複合構造レポート 05, 土木 学会, pp.63-76, 2012.6

4) 複合構造委員会編：FRP 部材の接合および鋼と FRP の接着接合に関する先端技術, 複合構造レポート 09, 土木学会, 2013.11

5）丹波寛夫，橋本国太郎，田中大介，杉浦邦征：腐食 した鋼桁端部の当て板補修に関する実験的検討, 構 造工学論文集, Vol.60A, pp.94-104, 2014.3

6) 小林洸貴, 近藤諒翼, 中村一史, 松本幸大, 松井孝 洋, 越智寬 : 真空含浸工法を応用した CFRP 接着に よる鋼析端腐食部の補修に関寸る実験的検討, 土木 
学会論文集 A1（構造・地震工学），Vol.73，No.5, pp.II_20-II_31, 2017.5

7) 奥山雄介, 宮下剛, 緒方辰男, 藤野和雄, 大垣賀津 雄, 秀熊佑哉, 堀本歴, 長井正嗣 : 鋼桁腹板の合理 的な補修・補強方法の確立に向けた FRP 接着鋼板の 一軸圧縮試験, 土木学会, 構造工学論文集, Vol.57A, pp.735-746, 2011.3

8) 高速道路総合技術研究所：炭素繊維シートによる鋼 構造物の補修・補強工法設計・施工マニュアル, p.24, 2013.10

(2017. 12. 11 受付)

\section{REPAIR AND STRENGTHEINING OF STEEL COMPRESSION MEMBERS USING CFRP MEMBERS FABRICATED BY VARTM TECHNIQUE}

\section{Akihiro MATSUYAMA, Jun SATO, Visal THAY, Hitoshi NAKAMURA, Yukihiro MATSUMOTO, Takahiro MATSUI and Yutaka OCHI}

The objective in this study is to develop a method of strengthening steel structures using externally bonded CFRP by VaRTM technique. As a fundamental study, the effect of strengthening of steel plates using proposed method under compressive force has been investigated experimentally and analytically. Buckling test has been conducted using steel plates with pinned ends varying the number of carbon fiber (CF) sheets. And the workability of VaRTM was also investigated in multi-layered CF sheets. Moreover, compression test has been conducted in order to improve the load carrying capacity of column members with section loss. As a column members of girder end, the patial models with section loss were fabricated and repaired using externally bonded CF sheets by VaRTM technique. 